\title{
Sociodemographic inequalities in the diet of young children in the 1946 British birth cohort
}

\author{
CJ Prynne ${ }^{1, *}$, AA Paul ${ }^{1}$, GD Mishra ${ }^{1}$, RJ Hardy ${ }^{2}$, C Bolton-Smith $^{1}$ and MEJ Wadsworth ${ }^{2}$ \\ ${ }^{1} M R C$ Human Nutrition Research, Elsie Widdowson Laboratory, Fulbourn Road, Cambridge CB1 9NL, UK: ${ }^{2}$ MRC \\ National Survey of Health and Development, University College and Royal Free Medical School, 1-19 Torrington \\ Place, London WC1E 6BT, UK
}

Submitted 4 October 2001: Accepted 1 March 2002

\begin{abstract}
Objective: To evaluate whether there was food and nutrient equality across occupational social classes and geographical region for members of the 1946 British birth cohort at age 4 years.

Design: Cross-sectional analysis of selected food groups, energy and nutrients from one-day recall diet records.

Setting: England, Scotland and Wales in 1950.

Subjects: Nationally representative sample of 4419 children aged 4 years in 1950 from the MRC National Survey of Health and Development (NSHD) (1946 Birth Cohort).

Results: Significant food and nutrient inequalities occurred by region and occupational social class of the father. Disparity in fruit and vegetable consumption primarily led to the nutrient differences, especially with respect to lower vitamin $\mathrm{C}$ and carotene intakes in children from Scotland and from a manual social class background. Lower energy intake in Scottish children was attributable to inequality in the consumption of foods providing fat, and also to the retention of the traditional Scottish diet that included porridge and soups. Consumption of some rationed foods - bacon, orange juice and tea - was inequitably distributed by father's social class, but others, in particular meat and spreading fats, were consumed more uniformly. In contrast to fruits and vegetables, which showed marked sociodemographic disparities, other non-rationed foods such as bread and potatoes were consumed universally.

Conclusion: Local cultural norms may have played as strong a part in sociodemographic differences in the diet of children in the early 1950s as did the strict, post-war food rationing that prevailed. In consequence, nutritional equality was not achieved, and the relatively low intake of antioxidant vitamins during early childhood in certain population groups may have compromised health in the long term.
\end{abstract}

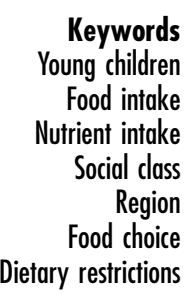

Epidemiologists have long recognised that there are variations in mortality rates and the incidence of disease between different regions of Britain. For example, agestandardised mortality rates for coronary heart disease show a clear rising gradient from Southern England to Scotland. In addition, disease and mortality are strongly related to social class; there is a consistent gradient of increasing mortality ratios from the highest occupational social class (SC I) to the lowest occupational social class $(\mathrm{SC} \mathrm{V})^{1}$. There is evidence that very early nutrition, as indicated by birth weight and weight at one year of age, may have an influence on adult health, particularly with respect to cardiovascular disease ${ }^{2}$. The generation of adults now at risk of developing heart disease was born during or just after World War 2 and would have been exposed to shortages and strict rationing of food during the gestational period and early life. They experienced a period of rapidly rising standards as they reached adulthood.

The chief published sources of data to study social and regional differences in diet at that time in Britain are the reports of the National Food Survey Committee in $1949^{3}$ and $1950^{4}$. These studies collected information on household food consumption and expenditure based on housewives' records of food purchases and changes in larder stocks. This information does not distinguish what individuals consumed. The 1950 national survey ${ }^{4}$ included both urban and rural households in England, Scotland and Wales. Comparison between social classes, defined by head of household incomes, showed that disparities in food consumption did exist but there is no information available as to what extent the diets of children were affected. The study of urban households in $1949^{3}$ included an analysis by region, demonstrating different household 
food-purchasing habits from the South to the North and in Scotland.

The present study forms part of a longitudinal study of the health and development of a national sample of babies born in $1946^{5}$. Dietary information was collected in 1950 , when the children were 4 years old, and these food records have recently been coded and analysed ${ }^{6}$. Currently it is unclear whether diet in early childhood, as distinct from in utero, has an effect on adult disease and mortality. Since food rationing was intended to ensure an equitable distribution of available supplies, it is pertinent to determine whether social and regional inequalities in diet did occur for these children, regardless of the restrictions in food supplies. Such information will form a foundation for investigating the relationship between childhood diet and disease as this cohort reaches middle and older age.

\section{Methods}

\section{Subjects and data collection}

The subjects were 4700 children living in England, Wales and Scotland who were 4 years old in 1950. They represented $88 \%$ of the 5362 children selected for the MRC National Survey of Health and Development (NSHD) (1946 Birth Cohort) as a social class stratified random sample of all of the legitimate, singleton babies born in the week of 3 rd to 9 th March $1946^{5}$. The sample contained all births to the wives of non-manual and agricultural workers plus a one in four random sample of those to manual workers.

A wide range of information about health, lifestyle and social background was collected by local Health Visitors at a home visit when the children were 4 years old ${ }^{7}$. The majority of these visits were in June (73\%) and July (19\%) 1950 , most of the rest took place during the 1950/1951 winter. Visits were spread through the week in approximately equal proportions from Monday to Friday (between 17 and 21\% of the total each), but only 3\% were on a Saturday and less than $1 \%$ on a Sunday. One-day recall diet records were obtained by asking the mother or carer 'What did this child have for each meal yesterday?' and referring specifically to 'breakfast', 'dinner', 'tea or high tea' and 'last thing at night'. The one other question which referred to food, asked whether the child had anything to eat between meals but did not ask for any details.

Of the 4700 children whose carer was interviewed, dietary information was obtained from 4599 (98\%). Table 1 shows the fathers' occupational social class ${ }^{8}$, and the regional distribution ${ }^{7}$ of the children. The small number of children ( $n=180)$ whose fathers were in the armed forces was omitted from all analyses, thus giving a sample size of 4419, comprising 2315 boys and 2104 girls. For a further eight children the region where they lived was not
Table 1 Social class and regional distribution of children in the MRC National Survey of Health and Development (NSHD) with dietary records at age 4 years in 1950

\begin{tabular}{lcr}
\hline & Number & Percentage \\
\hline NSHD initial sample & 5362 & \\
Number interviewed in 1950 & 4700 & \\
Number of dietary records & 4599 & \\
Number in armed forces & 180 & \\
\hline
\end{tabular}

\begin{tabular}{lrc}
\hline & \multicolumn{2}{c}{ Percentage of 4419} \\
\hline Number in present analysis & 4419 & 100 \\
Boys & 2315 & 52.4 \\
Girls & 2104 & 47.6 \\
Fathers' occupational social class & & \\
I & 259 & 5.9 \\
II & 728 & 16.5 \\
III Non Manual & 807 & 18.3 \\
III Manual & 1400 & 31.7 \\
IV & 934 & 21.1 \\
V & 291 & 6.6 \\
Region of residence & & \\
Scotland & 527 & 11.9 \\
North, North West, Yorkshire & 1119 & 25.3 \\
Midlands, North Midlands, & 1060 & 24.0 \\
Eastern & & \\
South West, Southern & 488 & 11.1 \\
Wales & 239 & 5.4 \\
London, South East & 978 & 22.1 \\
Not recorded & 8 & 0.2 \\
\hline
\end{tabular}

recorded, so they are not included in the analysis by region.

\section{Coding and nutrient analysis}

The diet records were coded using the in-house program DIDO $^{9}$, and nutrient analysis performed using the inhouse suite of programs based on McCance \& Widdowson's The Composition of Foods data ${ }^{10}$. Details of the dietary coding have been published previously ${ }^{6}$. In particular, appropriate nutritive values from contemporary sources ${ }^{11-13}$ were used for foods specific to 1950. Supplements such as cod liver oil or vitamin drops were not included in the dietary analysis since records were incomplete $^{6}$. Welfare orange juice was coded and analysed when it was recorded in a meal but it is not known if it was given between meals.

As only a few dietary records gave the weight of food consumed, portion sizes suitable for 4-year-olds were allocated using the amounts of rationed foods available ${ }^{14}$ (see Appendix) and Ministry of Health 1949 recommendations on feeding young children ${ }^{15}$. Since neither of these two sources separated boys and girls, no distinction could be made in the portion sizes for the two genders in the present analysis.

Nutrient analysis could only be carried out for food and drinks taken at meal times, as there were no details of food eaten between meals. Children of the manual social classes were more often given food to eat between meals (38\%) compared with those of the non-manual classes (25\%), but there were no significant differences among 
regions. There were a few gender differences in the consumption of certain foods but no significant $(P<0.01)$ differences in nutrient intake ${ }^{6}$, so, in the results presented below, the genders have not been separated. There were significant differences in the consumption of several foods on different days of the week, but no significant variation on this basis in energy and nutrient intakes ${ }^{6}$.

\section{Statistical analysis}

A binary variable was constructed to indicate whether or not a particular food was encountered at least once on the food record. This is referred to as 'consumption frequency'. Initial exploratory analyses involved calculating crude percentages and odds ratios (ORs) of consumption frequency for six categories of fathers' occupational social class and six geographical regions. Adjusted odds ratios and $95 \%$ confidence intervals (95\% CIs) of consumption frequency were estimated for fathers' social class (highest social class I as reference category) and region (Scotland as reference category) together, using multiple logistic regression. All odds ratios were also adjusted for the confounding binary variables of gender, season (summer: May-September, winter: October-April), the giving of foods between meals and whether the diet record covered a weekend or a weekday.

Means and 95\% confidence intervals for nutrient intakes were calculated for each category of fathers' social class and region in the same model, using the least square means option of the generalised linear models procedure of $\mathrm{SAS}^{16}$. Logarithmic transformations of retinol, carotene and vitamin $C$ were performed prior to analysis to normalise distributions. All means were adjusted for confounding variables as described above. Pair-wise comparisons of the mean nutrient intakes were performed for fathers' social class I compared with each of the other social class categories, and for region of residence with Scotland treated as reference category. Bonferroni corrections were used to reduce the effects of inflated type 1 errors due to multiple comparisons.

The same procedure as for nutrients was also used to examine the amounts of food consumed for the three foods that were consumed almost universally (bread, potatoes and milk). Interactions of food consumption frequency between the six regions and fathers' social class (manual/non-manual) were investigated using the generalised linear models procedure of SAS ${ }^{16}$.

\section{Results}

Results are presented for food and nutrient intakes obtained from the one-day diet records in 1950. Intakes refer only to food and drinks taken at meal times, as there were no details of food eaten between meals.

\section{Patterns offood consumption}

Table 2 shows the consumption frequency of certain foods and food groups by social class, with the adjusted odds ratios relative to the highest social class (I). The crude odds ratios are not reported, since they did not differ from the adjusted ones. Meat, bacon, cheese, fats, eggs, tea, sugar and sweets were still rationed in $1950^{14}$; details are given in the Appendix, Table A1. Bread, which was not rationed, and milk, which was free or subsidised for the under fives, were consumed almost universally and showed no differences between social classes. Nor were there any significant differences in the consumption frequencies of potatoes, spreading fats or meat. However, there was a very clear trend of decreasing frequency of consumption from the highest social class (SC I) to the lowest (SC V) of vegetables, fruit, orange juice, bacon and cake and biscuits. Frequency of vegetable consumption decreased from $90 \%$ in social class I to $78 \%$ in social class $\mathrm{V}$ (OR $=0.5 ; 95 \%$ CI $0.3,0.8)$, consumption of carrots fell from $12 \%$ to $2 \%(\mathrm{OR}=0.2 ; 95 \%$ CI $0.1,0.4)$ and fruit consumption fell from $59 \%$ to $29 \%$ (OR $=0.3$; 95\% CI 0.2 , 0.5). In contrast, consumption of chips increased from $8 \%$ in social class I to $16 \%$ in social class V $(\mathrm{OR}=1.9 ; 95 \% \mathrm{CI}$ $1.0,3.4)$ and tea consumption rose from $27 \%$ to $66 \%$ from the highest to the lowest social class (OR $=4.7$; $95 \%$ CI 3.2 , 6.8). The consumption of fish appeared to be very small, but it was strongly influenced by the day of the week for which the diet was recorded. Friday, the traditional day of fish consumption, was underrepresented in the study as relatively few interviews occurred on a Saturday ${ }^{6}$. Although milk and bread were consumed universally, there was a significant difference by social class in the quantities that were consumed: milk, $350 \mathrm{~g} \mathrm{day}^{-1}$ in SC I compared with $280-305 \mathrm{~g} \mathrm{day}^{-1}$ in the other social classes $(P<0.0001)$; and bread, $130 \mathrm{~g} \mathrm{day}^{-1}$ in SC $\mathrm{V}$ compared with $117 \mathrm{~g} \mathrm{day}^{-1}$ in SC I $(P=0.014)$.

Table 3 shows consumption frequency of foods by region with the adjusted odds ratios, relative to Scotland. Similar to the social class analysis, the crude and adjusted odds ratios did not differ. The Scottish diet was notably different from that of all other regions, even the North of England. Fruit and vegetables other than potatoes were consumed least frequently in Scotland, 34\% and 59\% respectively, and most often in London/South East, 55\% $(\mathrm{OR}=2.2 ; 95 \% \mathrm{CI} 1.8,2.8)$ and $90 \%(\mathrm{OR}=6.3 ; 95 \% \mathrm{CI} 4.8$, 8.3). Scotland also had the lowest consumption frequency of fried foods, 30\%, spreading fats, $76 \%$, and cakes, $52 \%$, whereas the highest consumption of fried foods was in the North of England, 43\% (OR = 1.8; 95\% CI 1.4, 2.3). The Scottish diet was further characterised by the frequent consumption of soup, 36\%, and porridge, 30\%, both of which were consumed by very few children from other regions. Children in Wales had the highest consumption of spreading fats, 95\% (OR $=5.5$; 95\% CI 3.1, 10.8). This corresponds with a significantly higher bread intake $\left(130 \mathrm{~g} \mathrm{day}^{-1}\right)$ in Wales than for children in Scotland, the Midlands and London/South East $\left(\sim 118 \mathrm{gday}^{-1}\right.$, $P<0.018)$. Children in the Midlands drank the least 
Table 2 Percentages, adjusted odds ratios and 95\% confidence intervals for the consumption of foods and food groups by 4-year-old children in 1950, according to fathers' social class

\begin{tabular}{|c|c|c|c|}
\hline & $\begin{array}{c}\text { Fathers' } \\
\text { social class* }\end{array}$ & Percentage $†$ & $\begin{array}{l}\text { Adjusted } \ddagger \text { odds ratio } \\
\text { (95\% confidence interval) }\end{array}$ \\
\hline Porridge & All & $11-12$ & NS \\
\hline Bread & All & $96-98$ & NS \\
\hline Cake, biscuits & $\begin{array}{l}\text { I } \\
\text { II } \\
\text { IIINM } \\
\text { IIIM } \\
\text { IV } \\
\text { V }\end{array}$ & $\begin{array}{l}71 \\
67 \\
64 \\
61 \\
57 \\
52\end{array}$ & 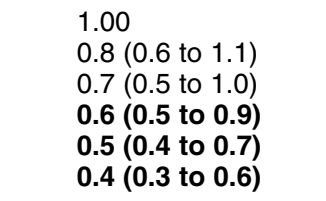 \\
\hline Milk & All & $97-98$ & NS \\
\hline Eggs & $\begin{array}{l}\text { I } \\
\text { II } \\
\text { IIINM } \\
\text { IIIM } \\
\text { IV } \\
\text { V }\end{array}$ & $\begin{array}{l}63 \\
56 \\
55 \\
54 \\
53 \\
57\end{array}$ & $\begin{array}{l}1.00 \\
0.7(0.5 \text { to } 1.0) \\
0.7(0.5 \text { to } 0.9) \\
0.5(0.5 \text { to } 0.9) \\
0.7(0.5 \text { to } 0.9) \\
0.8(0.5 \text { to } 1.1)\end{array}$ \\
\hline Spreading fats (R) & All & $85-88$ & NS \\
\hline Fried foods & All & $38-41$ & NS \\
\hline Bacon (R) & $\begin{array}{l}\text { I } \\
\text { II } \\
\text { IIINM } \\
\text { IIIM } \\
\text { IV } \\
\text { V }\end{array}$ & $\begin{array}{l}33 \\
34 \\
32 \\
26 \\
24 \\
21\end{array}$ & 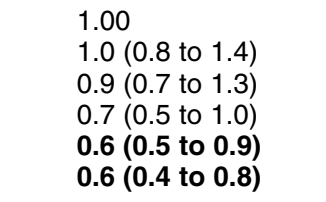 \\
\hline Meat \& dishes $(\mathrm{R})$ & All & $73-78$ & NS \\
\hline Potatoes & All & $86-90$ & NS \\
\hline Chips & $\begin{array}{l}\text { I } \\
\text { II } \\
\text { IIINM } \\
\text { IIIM } \\
\text { IV } \\
\text { V }\end{array}$ & $\begin{array}{r}8 \\
7 \\
10 \\
14 \\
14 \\
16\end{array}$ & $\begin{array}{l}1.00 \\
0.8(0.5 \text { to } 1.4) \\
1.2(0.8 \text { to } 2.1) \\
1.6(1.0 \text { to } 2.7) \\
1.6(1.0 \text { to } 2.7) \\
1.9(1.1 \text { to } 3.4)\end{array}$ \\
\hline Carrots & $\begin{array}{l}\text { I } \\
\text { II } \\
\text { IIINM } \\
\text { IIIM } \\
\text { IV } \\
\text { V }\end{array}$ & $\begin{array}{r}12 \\
8 \\
8 \\
6 \\
4 \\
2\end{array}$ & $\begin{array}{l}1.00 \\
0.6(0.4 \text { to } 1.0) \\
0.6(0.4 \text { to } 1.0) \\
0.4(0.3 \text { to } 0.7) \\
0.3(0.2 \text { to } 0.6) \\
\mathbf{0 . 2}(0.1 \text { to } 0.4)\end{array}$ \\
\hline Vegetables (excluding potatoes) & $\begin{array}{l}\text { I } \\
\text { II } \\
\text { IIINM } \\
\text { IIIM } \\
\text { IV } \\
\text { V }\end{array}$ & $\begin{array}{l}90 \\
85 \\
85 \\
80 \\
77 \\
78\end{array}$ & 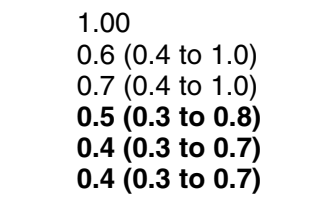 \\
\hline Fruit & $\begin{array}{l}\text { I } \\
\text { II } \\
\text { IIINM } \\
\text { IIIM } \\
\text { IV } \\
\text { V }\end{array}$ & $\begin{array}{l}59 \\
55 \\
54 \\
40 \\
37 \\
29\end{array}$ & $\begin{array}{l}1.00 \\
0.9(0.7 \text { to } 1.2) \\
0.8(0.6 \text { to } 1.1) \\
\mathbf{0 . 5}(\mathbf{0 . 4} \text { to } \mathbf{0 . 7}) \\
\mathbf{0 . 5}(\mathbf{0 . 3} \text { to } \mathbf{0 . 6}) \\
\mathbf{0 . 3}(\mathbf{0 . 2} \text { to } \mathbf{0 . 5})\end{array}$ \\
\hline Tea $(\mathrm{R})$ & $\begin{array}{l}\text { I } \\
\text { II } \\
\text { IIINM } \\
\text { IIIM } \\
\text { IV } \\
\text { V }\end{array}$ & $\begin{array}{l}27 \\
45 \\
51 \\
60 \\
62 \\
66\end{array}$ & $\begin{array}{l}1.00 \\
2.1(1.5 \text { to } 2.9) \\
2.7(2.0 \text { to } 3.7) \\
3.6(2.7 \text { to } 4.9) \\
3.9(2.9 \text { to } 5.3) \\
4.7(3.2 \text { to } 6.8)\end{array}$ \\
\hline
\end{tabular}


Table 2. Continued

\begin{tabular}{|c|c|c|c|}
\hline & $\begin{array}{c}\text { Fathers' } \\
\text { social class* }\end{array}$ & Percentage $†$ & $\begin{array}{l}\text { Adjusted } \neq \text { odds ratio } \\
\text { (95\% confidence interval) }\end{array}$ \\
\hline Orange juice (R) & $\begin{array}{l}\text { I } \\
\text { II } \\
\text { IIINM } \\
\text { IIIM } \\
\text { IV } \\
\text { V }\end{array}$ & $\begin{array}{r}22 \\
10 \\
17 \\
7 \\
7 \\
9\end{array}$ & 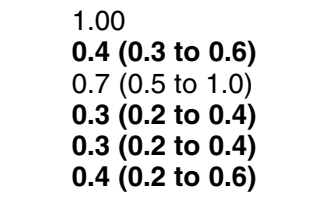 \\
\hline Soup & All & $6-9$ & NS \\
\hline
\end{tabular}

(R) indicates rationed food. NS - not significant.

* Sample size for each social class is as follows: 259 (I), 728 (II), 807 (IIINM), 1400 (IIIM), 934 (IV) and 291 (V).

$\dagger$ Percentage of children consuming the food at least once.

$\ddagger$ Adjusted for region, gender, season, weekday/weekend and food consumption between meals.

milk, $285 \mathrm{~g} \mathrm{day}^{-1}$, significantly lower than that of $\sim 312 \mathrm{~g} \mathrm{day}^{-1}$ in Scotland, the North/North West and London/South East $(P<0.015)$. Interactions between region and fathers' social class for food consumption frequency were significant only for vegetables, chips and soup. However, the numbers in the latter two groups were extremely small. Scotland again stood out as the region showing the greatest disparity in the frequency of vegetable consumption between the manual (53\%) and non-manual $(70 \%)$ social classes $(P<0.001)$, whereas vegetable consumption was virtually identical between manual and non-manual social classes in Wales, the South West and London/South East. Only 53\% of children of the manual workers in Scotland consumed vegetables compared with $78-90 \%$ of their counterparts in all other regions.

\section{Nutrient intakes}

Table 4 shows the means and 95\% confidence intervals for the energy and nutrient intakes of the survey children divided into six social classes. The intake of energy decreased from social class I $\left(6.4 \mathrm{MJ} \mathrm{day}^{-1}\right)$ to social class $\mathrm{V}\left(6.0 \mathrm{MJ} \mathrm{day}^{-1}\right)$, each manual social class being significantly different from social class I. There were similar significant decreases in nearly all nutrients; and the greatest differences between social class I and social class $\mathrm{V}$ were shown for vitamin C ( 42 to $28 \mathrm{mg} \mathrm{day}^{-1}$ ), carotene (819 to $545 \mu \mathrm{g} \mathrm{day}^{-1}$ ), sugar (70 to $58 \mathrm{~g} \mathrm{day}^{-1}$ ), calcium (808 to $692 \mathrm{mg} \mathrm{day}^{-1}$ ) and riboflavin ( 1.3 to $1.1 \mathrm{mg} \mathrm{day}^{-1}$ ). It has not been possible to include vitamin intakes from supplements, as this information was not recorded. There were no significant differences between the social classes in the proportions of energy derived from carbohydrate, protein or fat.

Table 5 shows the means and 95\% confidence intervals for the energy and nutrient intakes of the children according to six geographical regions. Similarly to food intake, Scotland stood out as being significantly different from all other regions by having the lowest mean intakes of energy, carbohydrate and fat. The lower energy intake,
5.7 $\mathrm{MJday}^{-1}$, can be related to the less frequent consumption of foods providing fat in the diet and to the low energy density of foods such as soup and porridge. The highest energy, $6.5 \mathrm{MJ} \mathrm{day}^{-1}$, and fat intakes were in Wales. Scotland also had significantly lower intakes of carotene, $498 \mu \mathrm{gday}^{-1}$, and vitamin C, $24 \mathrm{mg} \mathrm{day}^{-1}$, compared with other regions. The highest intakes of vitamin $\mathrm{C}\left(37 \mathrm{mg} \mathrm{day}^{-1}\right)$ and carotene $\left(785 \mu \mathrm{g} \mathrm{day}^{-1}\right.$ ) occurred in Southern England, closely reflecting consumption of fruit and vegetables. This pattern was consistent for the winter records, although the numbers were small $(n=177)$, as vitamin C intake in Scotland was considerably lower $\left(15 \mathrm{mg} \mathrm{day}^{-1}\right)$ than in all other regions (25-31 $\mathrm{mg} \mathrm{day}^{-1}$ ).

Calcium intake was lowest, but not significantly different, in the Midlands/North Midlands where the consumption of milk and bread was lower, and highest in Wales where more bread was eaten. The proportion of energy from protein was significantly higher in Scotland (14.5\%) than in all of the other regions (12.2 to 13.1\%), and the proportion of energy from carbohydrate was significantly lower in Scotland (45.5\%) compared with the North (47.2\%). There was no significant difference between regions in the percentage of energy from fat.

\section{Discussion}

In this study, significant sociodemographic variations in food and nutrient intake have been shown for the childhood diets of present-day adults. Social and regional dietary characteristics were resilient to the stringencies imposed by post-war food restrictions. These findings are particularly striking when the relatively limited amount of dietary information that was available is taken into consideration. Twenty-four-hour recall relies on memory, which can be prone to reporting error, to which are added errors in estimation of portion size, and social desirability of reporting may also have influenced the respondents' descriptions in different socio-economic groups. However, circumstances prevailing in 1950 may have mitigated 
Table 3 Percentages, adjusted odds ratios and 95\% confidence intervals for the consumption of foods and food groups by 4-year-old children in 1950, according to region

\begin{tabular}{|c|c|c|c|}
\hline & Region* & Percentage $\dagger$ & $\begin{array}{l}\text { Adjusted } \ddagger \text { odds ratio } \\
\text { (95\% confidence interval) }\end{array}$ \\
\hline Porridge & $\begin{array}{l}\text { Scotland } \\
\text { North, North West, Yorkshire } \\
\text { Midlands, North Midlands, Eastern } \\
\text { South West, Southern } \\
\text { Wales } \\
\text { London, South East }\end{array}$ & $\begin{array}{r}30 \\
11 \\
8 \\
8 \\
8 \\
10\end{array}$ & $\begin{array}{l}1.00 \\
0.3(0.2 \text { to } 0.4) \\
0.2(0.2 \text { to } 0.3) \\
0.2(0.1 \text { to } 0.3) \\
0.2(0.1 \text { to } 0.3) \\
0.3(0.2 \text { to } 0.3)\end{array}$ \\
\hline Bread & $\begin{array}{l}\text { Scotland } \\
\text { North, North West, Yorkshire } \\
\text { Midlands, North Midlands, Eastern } \\
\text { South West, Southern } \\
\text { Wales } \\
\text { London, South East }\end{array}$ & $\begin{array}{l}95 \\
97 \\
96 \\
97 \\
98 \\
98\end{array}$ & $\begin{array}{l}1.00 \\
1.7(1.0 \text { to } 2.9) \\
1.4(0.8 \text { to } 2.3) \\
1.8(0.9 \text { to } 3.5) \\
2.9(1.1 \text { to } 8.6) \\
2.1(1.2 \text { to } 3.7)\end{array}$ \\
\hline Cake, biscuits & $\begin{array}{l}\text { Scotland } \\
\text { North, North West, Yorkshire } \\
\text { Midlands, North Midlands, Eastern } \\
\text { South West, Southern } \\
\text { Wales } \\
\text { London, South East }\end{array}$ & $\begin{array}{l}52 \\
60 \\
63 \\
69 \\
66 \\
63\end{array}$ & $\begin{array}{l}1.00 \\
1.4(1.1 \text { to } 1.7) \\
1.5(1.2 \text { to } 1.9) \\
2.0(1.6 \text { to } 2.6) \\
1.9(1.3 \text { to } 2.6) \\
1.5(1.2 \text { to } 1.9)\end{array}$ \\
\hline Milk & All & $97-99$ & NS \\
\hline Eggs & $\begin{array}{l}\text { Scotland } \\
\text { North, North West, Yorkshire } \\
\text { Midlands, North Midlands, Eastern } \\
\text { South West, Southern } \\
\text { Wales } \\
\text { London, South East }\end{array}$ & $\begin{array}{l}64 \\
51 \\
53 \\
52 \\
50 \\
58\end{array}$ & $\begin{array}{l}1.00 \\
0.6(0.5 \text { to } 0.7) \\
0.6(0.5 \text { to } 0.8) \\
0.6(0.5 \text { to } 0.8) \\
0.6(0.4 \text { to } 0.8) \\
0.8(0.6 \text { to } 0.9)\end{array}$ \\
\hline Spreading fats $(\mathrm{R})$ & $\begin{array}{l}\text { Scotland } \\
\text { North, North West, Yorkshire } \\
\text { Midlands, North Midlands, Eastern } \\
\text { South West, Southern } \\
\text { Wales } \\
\text { London, South East }\end{array}$ & $\begin{array}{l}76 \\
83 \\
89 \\
91 \\
95 \\
86\end{array}$ & $\begin{array}{l}1.00 \\
1.5(1.2 \text { to } 1.9) \\
2.5(1.9 \text { to } 3.3) \\
3.0(2.1 \text { to } 4.4) \\
5.5(3.1 \text { to } 10.8) \\
1.9(1.5 \text { to } 2.6)\end{array}$ \\
\hline Fried foods & $\begin{array}{l}\text { Scotland } \\
\text { North, North West, Yorkshire } \\
\text { Midlands, North Midlands, Eastern } \\
\text { South West, Southern } \\
\text { Wales } \\
\text { London, South East }\end{array}$ & $\begin{array}{l}30 \\
43 \\
39 \\
37 \\
39 \\
40\end{array}$ & $\begin{array}{l}1.00 \\
1.8(1.4 \text { to } 2.3) \\
1.5(1.2 \text { to } 1.9) \\
1.4(1.1 \text { to } 1.9) \\
1.6(1.1 \text { to } 2.2) \\
1.6(1.2 \text { to } 2.0)\end{array}$ \\
\hline Bacon (R) & $\begin{array}{l}\text { Scotland } \\
\text { North, North West, Yorkshire } \\
\text { Midlands, North Midlands, Eastern } \\
\text { South West, Southern } \\
\text { Wales } \\
\text { London, South East }\end{array}$ & $\begin{array}{l}17 \\
28 \\
31 \\
27 \\
24 \\
32\end{array}$ & $\begin{array}{l}1.00 \\
1.9(1.5 \text { to } 2.5) \\
2.3(1.8 \text { to } 3.0) \\
1.8(1.3 \text { to } 2.4) \\
1.6(1.1 \text { to } 2.4) \\
2.3(1.7 \text { to } 3.0)\end{array}$ \\
\hline Meat \& dishes $(\mathrm{R})$ & All & $73-78$ & NS \\
\hline Potatoes & All & $87-90$ & NS \\
\hline Chips & $\begin{array}{l}\text { Scotland } \\
\text { North, North West, Yorkshire } \\
\text { Midlands, North Midlands, Eastern } \\
\text { South West, Southern } \\
\text { Wales } \\
\text { London, South East }\end{array}$ & $\begin{array}{r}12 \\
16 \\
11 \\
8 \\
18 \\
8\end{array}$ & $\begin{array}{l}1.00 \\
1.4(1.0 \text { to } 1.9) \\
0.9(0.6 \text { to } 1.2) \\
0.6(0.4 \text { to } 1.0) \\
1.7(1.1 \text { to } 2.6) \\
0.7(0.5 \text { to } 1.0)\end{array}$ \\
\hline Carrots & All & $5-8$ & NS \\
\hline Vegetables (excluding potatoes) & $\begin{array}{l}\text { Scotland } \\
\text { North, North West, Yorkshire } \\
\text { Midlands, North Midlands, Eastern } \\
\text { South West, Southern } \\
\text { Wales } \\
\text { London, South East }\end{array}$ & $\begin{array}{l}59 \\
80 \\
85 \\
84 \\
86 \\
90\end{array}$ & $\begin{array}{l}1.00 \\
3.0(2.4 \text { to } 3.8) \\
4.0(3.2 \text { to } 5.2) \\
3.9(2.9 \text { to } 5.3) \\
4.4(3.0 \text { to } 6.8) \\
6.3(4.8 \text { to } 8.3)\end{array}$ \\
\hline Fruit & $\begin{array}{l}\text { Scotland } \\
\text { North, North West, Yorkshire } \\
\text { Midlands, North Midlands, Eastern }\end{array}$ & $\begin{array}{l}34 \\
41 \\
42\end{array}$ & $\begin{array}{l}1.00 \\
1.4(1.1 \text { to } 1.7) \\
1.4(1.1 \text { to } 1.7)\end{array}$ \\
\hline
\end{tabular}


Table 3. Continued

\begin{tabular}{|c|c|c|c|}
\hline & Region* & Percentage & $\begin{array}{c}\text { Adjusted } \ddagger \text { odds ratio } \\
\text { (95\% confidence interval) }\end{array}$ \\
\hline & $\begin{array}{l}\text { South West, Southern } \\
\text { Wales } \\
\text { London, South East }\end{array}$ & $\begin{array}{l}46 \\
48 \\
55\end{array}$ & $\begin{array}{l}1.5(1.2 \text { to } 2.0) \\
1.8(1.3 \text { to } 2.5) \\
2.2(1.8 \text { to } 2.8)\end{array}$ \\
\hline Tea $(\mathrm{R})$ & $\begin{array}{l}\text { Scotland } \\
\text { North, North West, Yorkshire } \\
\text { Midlands, North Midlands, Eastern } \\
\text { South West, Southern } \\
\text { Wales } \\
\text { London, South East }\end{array}$ & $\begin{array}{l}61 \\
56 \\
55 \\
54 \\
63 \\
49\end{array}$ & $\begin{array}{l}1.00 \\
0.8(0.7 \text { to } 1.0) \\
0.8(0.6 \text { to } 1.0) \\
0.8(0.6 \text { to } 1.0) \\
1.2(0.9 \text { to } 1.7) \\
0.7(0.5 \text { to } 0.8)\end{array}$ \\
\hline Orange juice (R) & $\begin{array}{l}\text { Scotland } \\
\text { North, North West, Yorkshire } \\
\text { Midlands, North Midlands, Eastern } \\
\text { South West, Southern } \\
\text { Wales } \\
\text { London, South East }\end{array}$ & $\begin{array}{r}6 \\
9 \\
9 \\
13 \\
8 \\
14\end{array}$ & $\begin{array}{l}1.00 \\
1.6(1.1 \text { to } 2.5) \\
1.7(1.1 \text { to } 2.6) \\
2.1(1.4 \text { to } 3.4) \\
1.3(0.7 \text { to } 2.4) \\
2.3(1.5 \text { to } 3.5)\end{array}$ \\
\hline Soup & $\begin{array}{l}\text { Scotland } \\
\text { North, North West, Yorkshire } \\
\text { Midlands, North Midlands, Eastern } \\
\text { South West, Southern } \\
\text { Wales } \\
\text { London, South East }\end{array}$ & $\begin{array}{r}36 \\
4 \\
1 \\
1 \\
4 \\
2\end{array}$ & $\begin{array}{l}1.00 \\
0.1(0.0 \text { to } 0.1) \\
0.0(0.0 \text { to } 0.1) \\
0.0(0.0 \text { to } 0.1) \\
0.1(0.0 \text { to } 0.1) \\
0.0(0.0 \text { to } 0.1)\end{array}$ \\
\hline
\end{tabular}

$(\mathrm{R})$ indicates rationed food. NS - not significant.

* Sample size for each region is as follows: 527 (Scotland), 1119 (North, North West, Yorkshire), 1060 (Midlands, North Midlands, Eastern), 488 (South West, Southern), 239 (Wales) and 978 (London, South East).

†Percentage of children consuming the food at least once.

$\ddagger$ Adjusted for fathers' social class, gender, season, weekday/weekend and food consumption between meals.

these errors. The limited availability of foods would have made the mothers more focused on obtaining sufficient for the family and thus aided awareness during the reporting of their child's diet. Twenty-four-hour recall for large numbers of subjects is considered suitable for characterising group mean intakes although it is not appropriate for individual intakes ${ }^{17,18}$. Maximising the number of subjects and minimising the number of days is the most efficient way of improving the reliability of the mean for a given number of subject days ${ }^{18}$. Although less reliance can be placed on the calculations of nutrient intake, owing to the assignment of portion sizes, the mean results from the present study were mostly in good agreement with the national study of 78 children aged $4-5$ years conducted in 1951 using a seven-day weighed intake ${ }^{6,19}$. Total energy intake was also plausible in relation to calculated basal metabolic rate ${ }^{6}$.

An important aim of food rationing was to reduce inequalities of food distribution and consumption, which were considerable before the war. Studies carried out during the $1930 \mathrm{~s}$ by Crawford ${ }^{20}$ and Boyd Orr $^{21}$ showed considerable disparities between social classes in their intakes of particular foods, and there was concern that $18 \%{ }^{20}$ to $50 \%^{21}$ of the study populations had insufficient income to maintain a healthy diet. By 1950, the time of the first full National Food Survey ${ }^{4}$, and when some foods were still rationed, the inequalities of food distribution had decreased. Crawford had found that expenditure on food by the lowest income group was only one-third that of the highest but by 1950 the lowest-income group was spending three-quarters of that spent by the highest ${ }^{4}$. The levelling of expenditure was most marked with rationed foods such as eggs, butter and fresh meat.

None of the surveys discussed above make any reference to the food intake of children. However, results from the present study in children indicate that the inequalities described in the pre-war studies were only partly eradicated. These data are broadly in agreement with those of the National Food Survey of $1950^{4}$, in that there was a small downwards trend in the intakes of energy and macronutrients according to social class but a more pronounced difference in the intakes of vitamins and minerals. Milk was heavily subsidised or free for the under fives yet there was still a significant difference between social classes in the quantity of milk drunk by the present study children and, as a result, there was a significant difference in calcium intake. The patterns of fruit and vegetable intake also reflect both the pre-war findings of Crawford $^{20}$ and those of the 1950 National Food Survey ${ }^{4}$, both of which showed greater expenditure by the highest compared with the lowest social classes, although the disparity was less by 1950. Since the total vegetable consumption by the present study children showed a significant downwards gradation from social class I to social class V, carotene and vitamin $\mathrm{C}$ also followed a similar trend. Social factors, such as a lack of kitchen facilities 3,7 , could have been responsible for the greater consumption of chips by the children of manual workers. 
Table 4 Adjusted means and 95\% confidence intervals for daily intakes of energy and nutrients by 4 -year-old children in 1950, according to fathers' social class

\begin{tabular}{|c|c|c|c|c|}
\hline & $\begin{array}{c}\text { Fathers' } \\
\text { social class* }\end{array}$ & Mean† & $\begin{array}{l}95 \% \text { Confidence } \\
\text { interval }\end{array}$ & $P$-value $\ddagger$ \\
\hline Energy (MJ) & $\begin{array}{l}\text { I } \\
\text { II } \\
\text { IIINM } \\
\text { IIIM } \\
\text { IV } \\
\text { V }\end{array}$ & $\begin{array}{l}6.4 \\
6.2 \\
6.1 \\
6.0 \\
6.0 \\
6.0\end{array}$ & $\begin{array}{l}6.2 \text { to } 6.6 \\
6.1 \text { to } 6.4 \\
6.0 \text { to } 6.3 \\
5.9 \text { to } 6.1 \\
5.8 \text { to } 6.1 \\
5.8 \text { to } 6.2\end{array}$ & $\begin{array}{r}- \\
1.00 \\
0.25 \\
\mathbf{0 . 0 0 3} \\
<\mathbf{0 . 0 0 1} \\
\mathbf{0 . 0 3 0}\end{array}$ \\
\hline Protein $(\mathrm{g})$ & $\begin{array}{l}\text { I } \\
\text { II } \\
\text { IIINM } \\
\text { IIIM } \\
\text { IV } \\
\text { V }\end{array}$ & $\begin{array}{l}50 \\
47 \\
47 \\
46 \\
45 \\
45\end{array}$ & $\begin{array}{l}49 \text { to } 52 \\
46 \text { to } 49 \\
46 \text { to } 48 \\
45 \text { to } 47 \\
44 \text { to } 46 \\
44 \text { to } 47\end{array}$ & $\begin{array}{c}- \\
0.006 \\
<0.001 \\
<0.0001 \\
<0.0001 \\
<0.0001\end{array}$ \\
\hline Carbohydrate (g) & $\begin{array}{l}\text { I } \\
\text { II } \\
\text { IIINM } \\
\text { IIIM } \\
\text { IV } \\
\text { V }\end{array}$ & $\begin{array}{l}188 \\
183 \\
181 \\
178 \\
177 \\
179\end{array}$ & $\begin{array}{l}181 \text { to } 194 \\
178 \text { to } 188 \\
176 \text { to } 186 \\
174 \text { to } 183 \\
172 \text { to } 181 \\
172 \text { to } 185\end{array}$ & $\begin{array}{l}- \\
1.00 \\
0.97 \\
0.057 \\
0.017 \\
0.420\end{array}$ \\
\hline Sugar (g) & $\begin{array}{l}\text { I } \\
\text { II } \\
\text { IIINM } \\
\text { IIIM } \\
\text { IV } \\
\text { V }\end{array}$ & $\begin{array}{l}70 \\
67 \\
65 \\
61 \\
60 \\
58\end{array}$ & $\begin{array}{l}66 \text { to } 73 \\
65 \text { to } 70 \\
62 \text { to } 68 \\
59 \text { to } 63 \\
58 \text { to } 63 \\
55 \text { to } 62\end{array}$ & $\begin{array}{l}- \\
1.00 \\
0.10 \\
<\mathbf{0 . 0 0 0 1} \\
<\mathbf{0 . 0 0 0 1} \\
<\mathbf{0 . 0 0 0 1}\end{array}$ \\
\hline Fat $(\mathrm{g})$ & $\begin{array}{l}\text { I } \\
\text { II } \\
\text { IIINM } \\
\text { IIIM } \\
\text { IV } \\
\text { V }\end{array}$ & $\begin{array}{l}68 \\
67 \\
65 \\
64 \\
64 \\
63\end{array}$ & $\begin{array}{l}65 \text { to } 70 \\
64 \text { to } 68 \\
63 \text { to } 68 \\
62 \text { to } 66 \\
62 \text { to } 66 \\
61 \text { to } 66\end{array}$ & $\begin{array}{l}- \\
1.00 \\
1.00 \\
0.065 \\
0.061 \\
0.214\end{array}$ \\
\hline Iron (mg) & $\begin{array}{l}\text { I } \\
\text { II } \\
\text { IIINM } \\
\text { IIIM } \\
\text { IV } \\
\text { V }\end{array}$ & $\begin{array}{l}7.9 \\
7.6 \\
7.6 \\
7.5 \\
7.4 \\
7.6 \\
\end{array}$ & $\begin{array}{l}7.6 \text { to } 8.2 \\
7.4 \text { to } 7.9 \\
7.4 \text { to } 7.8 \\
7.3 \text { to } 7.7 \\
7.2 \text { to } 7.6 \\
7.3 \text { to } 7.9\end{array}$ & $\begin{array}{l}- \\
1.00 \\
0.84 \\
\mathbf{0 . 0 2 8} \\
\mathbf{0 . 0 0 8} \\
0.88\end{array}$ \\
\hline Calcium (mg) & $\begin{array}{l}\text { I } \\
\text { II } \\
\text { IIINM } \\
\text { IIIM } \\
\text { IV } \\
\text { V }\end{array}$ & $\begin{array}{l}808 \\
760 \\
739 \\
715 \\
699 \\
692\end{array}$ & $\begin{array}{l}775 \text { to } 841 \\
736 \text { to } 785 \\
715 \text { to } 763 \\
694 \text { to } 736 \\
676 \text { to } 722 \\
661 \text { to } 724\end{array}$ & $\begin{array}{l}- \\
0.057 \\
<\mathbf{0 . 0 0 1} \\
<\mathbf{0 . 0 0 0 1} \\
<\mathbf{0 . 0 0 0 1} \\
<\mathbf{0 . 0 0 0 1}\end{array}$ \\
\hline Magnesium (mg) & $\begin{array}{l}\text { I } \\
\text { II } \\
\text { IIINM } \\
\text { IIIM } \\
\text { IV } \\
\text { V }\end{array}$ & $\begin{array}{l}176 \\
168 \\
167 \\
165 \\
161 \\
162\end{array}$ & $\begin{array}{l}170 \text { to } 182 \\
164 \text { to } 173 \\
163 \text { to } 172 \\
161 \text { to } 168 \\
157 \text { to } 165 \\
156 \text { to } 167\end{array}$ & $\begin{array}{l}- \\
0.16 \\
0.066 \\
<\mathbf{0 . 0 0 1} \\
<\mathbf{0 . 0 0 0 1} \\
<\mathbf{0 . 0 0 1}\end{array}$ \\
\hline Phosphorus (mg) & $\begin{array}{l}\text { I } \\
\text { II } \\
\text { IIINM } \\
\text { IIIM } \\
\text { IV } \\
\text { V }\end{array}$ & $\begin{array}{l}994 \\
939 \\
916 \\
896 \\
874 \\
872\end{array}$ & $\begin{array}{l}960 \text { to } 1027 \\
914 \text { to } 964 \\
892 \text { to } 941 \\
874 \text { to } 917 \\
850 \text { to } 897 \\
840 \text { to } 904\end{array}$ & $\begin{array}{c}- \\
0.017 \\
<0.0001 \\
<0.0001 \\
<0.0001 \\
<0.0001\end{array}$ \\
\hline Potassium (mg) & $\begin{array}{l}\text { I } \\
\text { II } \\
\text { IIINM } \\
\text { IIIM } \\
\text { IV } \\
\text { V }\end{array}$ & $\begin{array}{l}1842 \\
1709 \\
1741 \\
1690 \\
1649 \\
1640\end{array}$ & $\begin{array}{l}1764 \text { to } 1920 \\
1650 \text { to } 1767 \\
1684 \text { to } 1797 \\
1640 \text { to } 1740 \\
1595 \text { to } 1703 \\
1565 \text { to } 1714\end{array}$ & $\begin{array}{l}- \\
\mathbf{0 . 0 1 0} \\
0.12 \\
<0.001 \\
<0.0001 \\
<\mathbf{0 . 0 0 1}\end{array}$ \\
\hline Zinc (mg) & $\begin{array}{c}\text { I } \\
\text { II } \\
\text { IIINM }\end{array}$ & $\begin{array}{l}6.9 \\
7.1 \\
6.6\end{array}$ & $\begin{array}{l}6.7 \text { to } 7.1 \\
6.6 \text { to } 6.9 \\
6.5 \text { to } 6.8\end{array}$ & $\begin{array}{l}- \\
1.00 \\
0.17\end{array}$ \\
\hline
\end{tabular}


Table 4. Continued

\begin{tabular}{|c|c|c|c|c|}
\hline & $\begin{array}{c}\text { Fathers' } \\
\text { social class* }\end{array}$ & Mean† & $\begin{array}{c}95 \% \text { Confidence } \\
\text { interval }\end{array}$ & $P$-value $\neq$ \\
\hline & $\begin{array}{l}\text { IIIM } \\
\text { IV } \\
\text { V }\end{array}$ & $\begin{array}{l}6.5 \\
6.4 \\
6.5\end{array}$ & $\begin{array}{l}6.4 \text { to } 6.7 \\
6.3 \text { to } 6.6 \\
6.3 \text { to } 6.7\end{array}$ & $\begin{array}{c}0.006 \\
<0.0001 \\
0.04\end{array}$ \\
\hline Retinol§ $(\mu \mathrm{g})$ & $\begin{array}{l}\text { I } \\
\text { II } \\
\text { IIINM } \\
\text { IIIM } \\
\text { IV } \\
\text { V }\end{array}$ & $\begin{array}{l}562 \\
546 \\
508 \\
514 \\
525 \\
496\end{array}$ & $\begin{array}{l}513 \text { to } 616 \\
510 \text { to } 584 \\
476 \text { to } 543 \\
485 \text { to } 547 \\
493 \text { to } 560 \\
455 \text { to } 541\end{array}$ & NS \\
\hline Carotene§ $(\mu \mathrm{g})$ & $\begin{array}{l}\text { I } \\
\text { II } \\
\text { IIINM } \\
\text { IIIM } \\
\text { IV } \\
\text { V }\end{array}$ & $\begin{array}{l}819 \\
685 \\
686 \\
592 \\
579 \\
545\end{array}$ & $\begin{array}{l}712 \text { to } 936 \\
618 \text { to } 759 \\
621 \text { to } 757 \\
542 \text { to } 646 \\
526 \text { to } 637 \\
477 \text { to } 620\end{array}$ & $\begin{array}{l}- \\
0.15 \\
0.11 \\
<\mathbf{0 . 0 0 0 1} \\
<\mathbf{0 . 0 0 0 1} \\
<\mathbf{0 . 0 0 0 1}\end{array}$ \\
\hline Thiamin (mg) & $\begin{array}{l}\text { I } \\
\text { II } \\
\text { IIINM } \\
\text { IIIM } \\
\text { IV } \\
\text { V }\end{array}$ & $\begin{array}{l}0.76 \\
0.73 \\
0.72 \\
0.70 \\
0.69 \\
0.67\end{array}$ & $\begin{array}{l}0.73 \text { to } 0.79 \\
0.71 \text { to } 0.75 \\
0.70 \text { to } 0.74 \\
0.68 \text { to } 0.72 \\
0.67 \text { to } 0.71 \\
0.65 \text { to } 0.70\end{array}$ & $\begin{array}{l}- \\
0.31 \\
0.05 \\
<\mathbf{0 . 0 0 0 1} \\
<\mathbf{0 . 0 0 0 1} \\
<\mathbf{0 . 0 0 0 1}\end{array}$ \\
\hline Riboflavin (mg) & $\begin{array}{l}\text { I } \\
\text { II } \\
\text { IIINM } \\
\text { IIIM } \\
\text { IV } \\
\text { V }\end{array}$ & $\begin{array}{l}1.3 \\
1.2 \\
1.2 \\
1.2 \\
1.1 \\
1.1\end{array}$ & $\begin{array}{l}1.3 \text { to } 1.4 \\
1.2 \text { to } 1.3 \\
1.1 \text { to } 1.2 \\
1.1 \text { to } 1.2 \\
1.1 \text { to } 1.2 \\
1.0 \text { to } 1.2\end{array}$ & $\begin{array}{c}-\overline{0} \\
\mathbf{0} 024 \\
<0.001 \\
<0.0001 \\
<0.0001 \\
<0.0001\end{array}$ \\
\hline Niacin (mg) & $\begin{array}{l}\text { I } \\
\text { II } \\
\text { IIINM } \\
\text { IIIM } \\
\text { IV } \\
\text { V }\end{array}$ & $\begin{array}{l}7.5 \\
7.3 \\
7.4 \\
7.1 \\
7.1 \\
7.1 \\
7.1\end{array}$ & $\begin{array}{l}7.2 \text { to } 7.8 \\
7.0 \text { to } 7.5 \\
7.1 \text { to } 7.6 \\
6.9 \text { to } 7.3 \\
6.8 \text { to } 7.3 \\
6.7 \text { to } 7.4\end{array}$ & NS \\
\hline Vitamin C§ (mg) & $\begin{array}{l}\text { I } \\
\text { II } \\
\text { IIINM } \\
\text { IIIM } \\
\text { IV } \\
\text { V }\end{array}$ & $\begin{array}{l}42 \\
36 \\
37 \\
32 \\
31 \\
28\end{array}$ & $\begin{array}{l}38 \text { to } 46 \\
34 \text { to } 38 \\
35 \text { to } 39 \\
30 \text { to } 34 \\
29 \text { to } 33 \\
26 \text { to } 31\end{array}$ & $\begin{array}{l}\overline{0} \\
\mathbf{0} 020 \\
0.04 \\
<0.0001 \\
<0.0001 \\
<0.0001\end{array}$ \\
\hline Vitamin E (mg) & $\begin{array}{l}\text { I } \\
\text { II } \\
\text { IIINM } \\
\text { IIIM } \\
\text { IV } \\
\text { V }\end{array}$ & $\begin{array}{l}2.8 \\
2.7 \\
2.6 \\
2.5 \\
2.4 \\
2.4\end{array}$ & $\begin{array}{l}2.7 \text { to } 2.9 \\
2.6 \text { to } 2.8 \\
2.5 \text { to } 2.7 \\
2.4 \text { to } 2.5 \\
2.4 \text { to } 2.5 \\
2.3 \text { to } 2.5\end{array}$ & $\begin{array}{l}- \\
0.18 \\
\mathbf{0 . 0 0 2} \\
<\mathbf{0 . 0 0 0 1} \\
<0.0001 \\
<0.0001\end{array}$ \\
\hline
\end{tabular}

NS - not significant.

* Sample size for each social class is as follows: 259 (I), 728 (II), 807 (IIINM), 1400 (IIIM), 934 (IV) and 291 (V).

†Adjusted for region, gender, season, weekday/weekend and food consumption between meals.

$\ddagger P$-values, for social class $I$ as reference category, have also been adjusted for multiple comparisons.

$\S$ Geometric mean.

Although the analysis was adjusted for season, it must be remembered that the results are from a predominantly summer survey and they might have been slightly different if more of the records had dated from the winter months.

The present results show that rationing did achieve a more equitable distribution of foods such as meat and fats. However, other rationed foods still showed marked social gradients. Bacon was more popular in the non-manual social classes, while tea showed the opposite trend. Welfare orange juice appeared to be consumed more by the non-manual social classes, although it is possible that this was under-recorded through not having details of items given to the children between meals. Cakes and biscuits were also consumed more frequently at meals by 
Table 5 Adjusted means and $95 \%$ confidence intervals for daily intakes of energy and nutrients by 4-year-old children in 1950, according to region

\begin{tabular}{|c|c|c|c|c|}
\hline & Region* & Mean† & $\begin{array}{l}\text { 95\% Confidence } \\
\text { interval }\end{array}$ & $P$-value $\ddagger$ \\
\hline Energy (MJ) & $\begin{array}{l}\text { Scotland } \\
\text { North, North West, Yorkshire } \\
\text { Midlands, North Midlands, Eastern } \\
\text { South West, Southern } \\
\text { Wales } \\
\text { London, South East }\end{array}$ & $\begin{array}{l}5.7 \\
6.2 \\
6.0 \\
6.2 \\
6.5 \\
6.1\end{array}$ & $\begin{array}{l}5.5 \text { to } 5.8 \\
6.1 \text { to } 6.4 \\
5.9 \text { to } 6.2 \\
6.0 \text { to } 6.3 \\
6.3 \text { to } 6.7 \\
6.0 \text { to } 6.3\end{array}$ & $\begin{array}{l}<- \\
<0.0001 \\
<0.0001 \\
<0.0001 \\
<0.0001 \\
<0.0001\end{array}$ \\
\hline Protein $(\mathrm{g})$ & $\begin{array}{l}\text { Scotland } \\
\text { North, North West, Yorkshire } \\
\text { Midlands, North Midlands, Eastern } \\
\text { South West, Southern } \\
\text { Wales } \\
\text { London, South East }\end{array}$ & $\begin{array}{l}48 \\
47 \\
45 \\
46 \\
47 \\
47\end{array}$ & $\begin{array}{l}47 \text { to } 49 \\
46 \text { to } 49 \\
44 \text { to } 47 \\
44 \text { to } 47 \\
45 \text { to } 48 \\
46 \text { to } 48\end{array}$ & $\begin{array}{l}- \\
1.00 \\
<0.001 \\
<0.001 \\
1.00 \\
1.00\end{array}$ \\
\hline Carbohydrate (g) & $\begin{array}{l}\text { Scotland } \\
\text { North, North West, Yorkshire } \\
\text { Midlands, North Midlands, Eastern } \\
\text { South West, Southern } \\
\text { Wales } \\
\text { London, South East }\end{array}$ & $\begin{array}{l}164 \\
187 \\
178 \\
182 \\
194 \\
180\end{array}$ & $\begin{array}{l}160 \text { to } 170 \\
182 \text { to } 191 \\
174 \text { to } 183 \\
177 \text { to } 188 \\
187 \text { to } 201 \\
175 \text { to } 185\end{array}$ & $\begin{array}{l}<- \\
<0.0001 \\
<0.0001 \\
<0.0001 \\
<0.0001 \\
<0.0001\end{array}$ \\
\hline Sugar (g) & $\begin{array}{l}\text { Scotland } \\
\text { North, North West, Yorkshire } \\
\text { Midlands, North Midlands, Eastern } \\
\text { South West, Southern } \\
\text { Wales } \\
\text { London, South East }\end{array}$ & $\begin{array}{l}56 \\
64 \\
63 \\
65 \\
66 \\
66\end{array}$ & $\begin{array}{l}53 \text { to } 59 \\
62 \text { to } 67 \\
61 \text { to } 66 \\
63 \text { to } 68 \\
63 \text { to } 70 \\
64 \text { to } 68\end{array}$ & $\begin{array}{l}<\overline{<} \\
<0001 \\
<0.0001 \\
<0.0001 \\
<0.0001 \\
<0.0001\end{array}$ \\
\hline Fat $(\mathrm{g})$ & $\begin{array}{l}\text { Scotland } \\
\text { North, North West, Yorkshire } \\
\text { Midlands, North Midlands, Eastern } \\
\text { South West, Southern } \\
\text { Wales } \\
\text { London, South East }\end{array}$ & $\begin{array}{l}60 \\
65 \\
64 \\
66 \\
70 \\
65\end{array}$ & $\begin{array}{l}57 \text { to } 62 \\
63 \text { to } 67 \\
62 \text { to } 66 \\
63 \text { to } 68 \\
67 \text { to } 73 \\
63 \text { to } 67\end{array}$ & $\begin{array}{l}<- \\
<0.0001 \\
<0.0001 \\
<0.0001 \\
<0.0001 \\
<0.0001\end{array}$ \\
\hline Iron (mg) & $\begin{array}{l}\text { Scotland } \\
\text { North, North West, Yorkshire } \\
\text { Midlands, North Midlands, Eastern } \\
\text { South West, Southern } \\
\text { Wales } \\
\text { London, South East }\end{array}$ & $\begin{array}{l}7.2 \\
7.8 \\
7.5 \\
7.6 \\
7.6 \\
7.8\end{array}$ & $\begin{array}{l}6.9 \text { to } 7.4 \\
7.6 \text { to } 8.0 \\
7.3 \text { to } 7.7 \\
7.4 \text { to } 7.9 \\
7.3 \text { to } 7.9 \\
7.6 \text { to } 8.0\end{array}$ & $\begin{array}{c}-\overline{0} \\
\mathbf{0 . 0 0 0 1} \\
\mathbf{0 . 0 1 9} \\
0.004 \\
0.095 \\
<0.0001\end{array}$ \\
\hline Calcium (mg) & $\begin{array}{l}\text { Scotland } \\
\text { North, North West, Yorkshire } \\
\text { Midlands, North Midlands, Eastern } \\
\text { South West, Southern } \\
\text { Wales } \\
\text { London, South East }\end{array}$ & $\begin{array}{l}732 \\
741 \\
706 \\
728 \\
759 \\
748\end{array}$ & $\begin{array}{l}706 \text { to } 759 \\
719 \text { to } 763 \\
683 \text { to } 728 \\
701 \text { to } 755 \\
725 \text { to } 792 \\
725 \text { to } 771\end{array}$ & NS \\
\hline Magnesium (mg) & $\begin{array}{l}\text { Scotland } \\
\text { North, North West, Yorkshire } \\
\text { Midlands, North Midlands, Eastern } \\
\text { South West, Southern } \\
\text { Wales } \\
\text { London, South East }\end{array}$ & $\begin{array}{l}160 \\
171 \\
163 \\
165 \\
171 \\
169\end{array}$ & $\begin{array}{l}155 \text { to } 164 \\
169 \text { to } 175 \\
159 \text { to } 167 \\
161 \text { to } 170 \\
165 \text { to } 177 \\
165 \text { to } 173\end{array}$ & $\begin{array}{l}<\overline{\mathbf{0}} \mathbf{0 0 0 1} \\
1.00 \\
0.40 \\
\mathbf{0 . 0 0 5} \\
<\mathbf{0 . 0 0 1}\end{array}$ \\
\hline Phosphorus (mg) & $\begin{array}{l}\text { Scotland } \\
\text { North, North West, Yorkshire } \\
\text { Midlands, North Midlands, Eastern } \\
\text { South West, Southern } \\
\text { Wales } \\
\text { London, South East }\end{array}$ & $\begin{array}{l}905 \\
937 \\
890 \\
903 \\
931 \\
924\end{array}$ & $\begin{array}{l}878 \text { to } 932 \\
915 \text { to } 960 \\
868 \text { to } 913 \\
876 \text { to } 931 \\
896 \text { to } 965 \\
901 \text { to } 947\end{array}$ & NS \\
\hline Potassium (mg) & $\begin{array}{l}\text { Scotland } \\
\text { North, North West, Yorkshire } \\
\text { Midlands, North Midlands, Eastern } \\
\text { South West, Southern } \\
\text { Wales } \\
\text { London, South East }\end{array}$ & $\begin{array}{l}1668 \\
1769 \\
1668 \\
1668 \\
1766 \\
1730\end{array}$ & $\begin{array}{l}1606 \text { to } 1731 \\
1717 \text { to } 1821 \\
1615 \text { to } 1721 \\
1604 \text { to } 1733 \\
1687 \text { to } 1846 \\
1676 \text { to } 1785\end{array}$ & $\begin{array}{l}- \\
\mathbf{0 . 0 0 6} \\
1.00 \\
1.00 \\
0.28 \\
0.47\end{array}$ \\
\hline Zinc (mg) & $\begin{array}{l}\text { Scotland } \\
\text { North, North West, Yorkshire } \\
\text { Midlands, North Midlands, Eastern }\end{array}$ & $\begin{array}{l}6.8 \\
6.8 \\
6.4\end{array}$ & $\begin{array}{l}6.6 \text { to } 7.0 \\
6.6 \text { to } 6.9 \\
6.3 \text { to } 6.6\end{array}$ & $\begin{array}{l}- \\
1.00 \\
<\mathbf{0 . 0 0 0 1}\end{array}$ \\
\hline
\end{tabular}


Table 5. Continued

\begin{tabular}{|c|c|c|c|c|}
\hline & Region* & Mean† & $\begin{array}{l}\text { 95\% Confidence } \\
\text { interval }\end{array}$ & $P$-value $\ddagger$ \\
\hline & $\begin{array}{l}\text { South West, Southern } \\
\text { Wales } \\
\text { London, South East }\end{array}$ & $\begin{array}{l}6.5 \\
6.6 \\
6.6\end{array}$ & $\begin{array}{l}6.3 \text { to } 6.6 \\
6.4 \text { to } 6.8 \\
6.5 \text { to } 6.8\end{array}$ & $\begin{array}{l}\mathbf{0 . 0 0 5} \\
1.00 \\
0.20\end{array}$ \\
\hline Retinol§ $(\mu \mathrm{g})$ & $\begin{array}{l}\text { Scotland } \\
\text { North, North West, Yorkshire } \\
\text { Midlands, North Midlands, Eastern } \\
\text { South West, Southern } \\
\text { Wales } \\
\text { London, South East }\end{array}$ & $\begin{array}{l}494 \\
510 \\
516 \\
529 \\
555 \\
541\end{array}$ & $\begin{array}{l}459 \text { to } 532 \\
480 \text { to } 542 \\
485 \text { to } 549 \\
490 \text { to } 570 \\
505 \text { to } 609 \\
508 \text { to } 577\end{array}$ & NS \\
\hline Carotene§ $(\mu \mathrm{g})$ & $\begin{array}{l}\text { Scotland } \\
\text { North, North West, Yorkshire } \\
\text { Midlands, North Midlands, Eastern } \\
\text { South West, Southern } \\
\text { Wales } \\
\text { London, South East }\end{array}$ & $\begin{array}{l}498 \\
612 \\
665 \\
707 \\
632 \\
785\end{array}$ & $\begin{array}{l}446 \text { to } 555 \\
558 \text { to } 671 \\
606 \text { to } 728 \\
632 \text { to } 788 \\
550 \text { to } 727 \\
715 \text { to } 863\end{array}$ & $\begin{array}{r}- \\
0.0008 \\
<0.0001 \\
<0.0001 \\
0.020 \\
<0.0001\end{array}$ \\
\hline Thiamin (mg) & $\begin{array}{l}\text { Scotland } \\
\text { North, North West, Yorkshire } \\
\text { Midlands, North Midlands, Eastern } \\
\text { South West, Southern } \\
\text { Wales } \\
\text { London, South East }\end{array}$ & $\begin{array}{l}0.69 \\
0.73 \\
0.70 \\
0.70 \\
0.73 \\
0.73\end{array}$ & $\begin{array}{l}0.67 \text { to } 0.71 \\
0.71 \text { to } 0.75 \\
0.68 \text { to } 0.72 \\
0.68 \text { to } 0.72 \\
0.70 \text { to } 0.76 \\
0.71 \text { to } 0.75\end{array}$ & $\begin{array}{l}\overline{\mathbf{0}} .001 \\
1.00 \\
1.00 \\
0.051 \\
\mathbf{0 . 0 0 1}\end{array}$ \\
\hline Riboflavin (mg) & $\begin{array}{l}\text { Scotland } \\
\text { North, North West, Yorkshire } \\
\text { Midlands, North Midlands, Eastern } \\
\text { South West, Southern } \\
\text { Wales } \\
\text { London, South East }\end{array}$ & $\begin{array}{l}1.2 \\
1.2 \\
1.1 \\
1.2 \\
1.2 \\
1.2\end{array}$ & $\begin{array}{l}1.1 \text { to } 1.2 \\
1.2 \text { to } 1.2 \\
1.1 \text { to } 1.2 \\
1.1 \text { to } 1.2 \\
1.1 \text { to } 1.3 \\
1.2 \text { to } 1.3\end{array}$ & NS \\
\hline Niacin (mg) & $\begin{array}{l}\text { Scotland } \\
\text { North, North West, Yorkshire } \\
\text { Midlands, North Midlands, Eastern } \\
\text { South West, Southern } \\
\text { Wales } \\
\text { London, South East }\end{array}$ & $\begin{array}{l}7.0 \\
7.3 \\
7.2 \\
7.1 \\
7.3 \\
7.4\end{array}$ & $\begin{array}{l}6.7 \text { to } 7.3 \\
7.1 \text { to } 7.5 \\
7.0 \text { to } 7.4 \\
6.9 \text { to } 7.4 \\
7.0 \text { to } 7.7 \\
7.0 \text { to } 7.6\end{array}$ & NS \\
\hline Vitamin C§ (mg) & $\begin{array}{l}\text { Scotland } \\
\text { North, North West, Yorkshire } \\
\text { Midlands, North Midlands, Eastern } \\
\text { South West, Southern } \\
\text { Wales } \\
\text { London, South East }\end{array}$ & $\begin{array}{l}24 \\
32 \\
35 \\
37 \\
33 \\
37\end{array}$ & $\begin{array}{l}22 \text { to } 26 \\
30 \text { to } 34 \\
33 \text { to } 37 \\
35 \text { to } 40 \\
30 \text { to } 37 \\
35 \text { to } 40\end{array}$ & $\begin{array}{l}<\overline{-} \\
<0.0001 \\
<0.0001 \\
<0.0001 \\
<0.0001\end{array}$ \\
\hline Vitamin E (mg) & $\begin{array}{l}\text { Scotland } \\
\text { North, North West, Yorkshire } \\
\text { Midlands, North Midlands, Eastern } \\
\text { South West, Southern } \\
\text { Wales } \\
\text { London, South East }\end{array}$ & $\begin{array}{l}2.4 \\
2.5 \\
2.5 \\
2.6 \\
2.7 \\
2.6\end{array}$ & $\begin{array}{l}2.3 \text { to } 2.5 \\
2.4 \text { to } 2.5 \\
2.5 \text { to } 2.6 \\
2.5 \text { to } 2.7 \\
2.6 \text { to } 2.8 \\
2.5 \text { to } 2.7\end{array}$ & $\begin{array}{l}- \\
1.00 \\
0.42 \\
\mathbf{0 . 0 1 6} \\
<\mathbf{0 . 0 0 1} \\
<\mathbf{0 . 0 0 1}\end{array}$ \\
\hline
\end{tabular}

NS - not significant.

* Sample size for each region is as follows: 527 (Scotland), 1119 (North, North West, Yorkshire), 1060 (Midlands, North Midlands, Eastern), 488 (South West, Southern), 239 (Wales) and 978 (London, South East). † Adjusted for fathers' social class, gender, season, weekday/weekend and food consumption between meals. $\ddagger P$-values, for Scotland as reference category, have also been adjusted for multiple comparisons. $\S$ Geometric mean.

the non-manual than the manual social classes, but they could also have been consumed between meals and so have been under-recorded. Their availability would have been dependent on the rations for eggs, sugar and fats, and these ingredients may have been used in different ways between the social classes. Bread and potatoes, which were not rationed, were almost universally consumed. In contrast, fruit and vegetables, which were also not rationed, showed considerable disparities between social classes. These disparities may have been due to the cost of non-rationed foods. As post-war food prices were rising a reduction in the consumption of expensive foods such as fruit and vegetables would act as a check on increasing food budgets ${ }^{4}$. It is also likely that there was a better response by the more educated classes to the health messages from the Ministry of Food ${ }^{22}$. In particular, the uptake of welfare orange juice nationally was higher in the non-manual classes ${ }^{23}$. 
Significant differences were shown to exist in the present study between the diets of children who were living in different regions. These might have been due to local habits and traditions, food distribution and seasonality of supply. The frequent consumption of soup and porridge, the preference for stews over fried food and the avoidance of bacon indicated that, despite food rationing, the diet in Scotland retained its national characteristics $^{24-26}$. Oatmeal porridge, milk and a broth containing some meat and vegetables appears to have been the mainstay of the Scottish diet for several centuries. Poor distribution of the wide range of summer fruits and vegetables available in the South of England in 1950 may have contributed to the overall lower consumption of these foods in Scotland compared with elsewhere. However, even the North of England was significantly different from Scotland, which was also shown in the survey of urban diets in $1949^{3}$. Apart from onions and root vegetables, the staple ingredients of soups and stews, the only vegetable characteristic of Scotland was kale ${ }^{27}$. This winter vegetable was not encountered in the present study, which was carried out predominantly during the summer. It would appear that the situation in $1950 \mathrm{was}$ not necessarily due just to problems of distribution and short supply since the low consumption of fruits and vegetables is of continuing concern in Scotland, both with regard to children $^{28}$ and adults ${ }^{29}$. As such, both economics and characteristics of the national diet are likely to have been important.

The nutritional consequence of a diet lower in fruit and vegetables, as eaten by the children in Scotland, and particularly those of lower socio-economic status, was a reduced intake of the antioxidant nutrients. These children may have been at greater risk of childhood illness as well as having potentially less protection against degenerative disease in later life. The most socially deprived regions of Scotland have the highest mortality from coronary heart disease in Britain, and evidence from the Scottish Heart Health Study ${ }^{29,30}$ suggested that lack of fruit and vegetables in the diet may possibly play a role in addition to the classical risk factors for cardiovascular disease. In agreement with this was a study of elderly Swedish men who had been followed for 26 years ${ }^{31}$, since daily fruit consumption seemed to have a positive effect on longterm survival independently of traditional risk factors such as smoking, high blood pressure and plasma cholesterol.

Saturated fat is considered a strong risk factor for cardiovascular disease and tends to correlate well with total fat intake. However, in the present study, childhood intake of fat, as a percentage of total energy, was not related to the sociodemographics of heart disease risk, whilst, theoretically, consumption of oatmeal porridge could contribute to lower cholesterol levels ${ }^{32}$.

Poor diet in childhood may have long-term health risks, as suggested by the evidence that cholesterol levels and initial lesions of arteriosclerosis may be established in childhood $^{33-35}$ and by the long-term effects of pulmonary disease in early life ${ }^{36,37}$, the risk of which is probably reduced by adequate antioxidant intake ${ }^{38,39}$. If dietary habits track with age, there will be a continuing health risk of long-term low antioxidant intake that is likely to contribute to risk of degenerative disease. Evidence that dietary habits do persist is demonstrated by the retention of some of the characteristic social and regional differences by the present study children into early adulthood ${ }^{40}$.

In this age group, social and regional dietary characteristics were resilient to the stringencies imposed by wartime food restrictions. In a comparison of these children's diet in 1950 with that of children in 1992/3, the diet in the earlier born cohort was arguably better in some important respects ${ }^{6}$. Comparable studies of dietary inequality in childhood in later born cohorts, as well as the continued follow-up of this cohort into older age, will further address the importance of interactions between nutrition and sociodemographic factors in disease and functional change with age.

\section{Acknowledgement}

This study was funded by the Medical Research Council.

\section{References}

1 Macintyre S. The patterning of health by social position in contemporary Britain: directions for sociological research. Soc. Sci. Med. 1986; 23(4): 393-415.

2 Barker DJP. The intrauterine environment and adult cardiovascular disease. In: The Childhood Environment and Adult Disease. Ciba Foundation Symposium 156. Chichester: Wiley, 1991; 3-16.

3 Ministry of Agriculture, Fisheries and Food. Studies in Urban Household Diets 1944-49. London: HMSO, 1956.

4 Ministry of Food. Domestic Food Consumption and Expenditure, 1950. London: HMSO, 1952.

5 Wadsworth MEJ. The Imprint of Time. Oxford: Clarendon Press, 1991.

6 Prynne CJ, Paul AA, Price GM, Day KC, Hilder WS, Wadsworth MEJ. Food and nutrient intake of a national sample of 4-year-old children in 1950: comparison with the 1990s. Public Health Nutr. 1999; 2(4): 537-47.

7 Douglas JWB, Blomfeld JM. Children under Five. London: Allen and Unwin, 1958.

8 Registrar General. Classification of Occupations. London: HMSO, 1961.

9 Price GM, Paul AA, Key FB, et al. Measurement of diet in a large national survey: comparison of computerised and manual coding in household measures. J. Hum. Nutr. Diet. 1995; 8: 417-28.

10 Paul AA, Southgate DAT. McCance \& Widdowson's The Composition of Foods, 4th ed. London: HMSO, 1978.

11 McCance RA, Widdowson EM. The Chemical Composition of Foods, 2nd ed. London: HMSO, 1946.

12 Medical Research Council. Nutritive Values of Wartime Foods. London: HMSO, 1945.

13 Ward RJ. The vitamin E content of margarine. Br. J. Nutr. 1958; 12: 231-6.

14 Ministry of Food. ABC of Rationing in the United Kingdom. London: Ministry of Food, 1951. 
15 Ministry of Health. The Feeding of Young Children from One to Five. London: HMSO, 1949.

16 SAS Institute, Inc. SAS/STAT Users Guide, Version 6. Vol. 2, 4th ed. Cary, NC: SAS Institute, Inc., 1989.

17 Beaton GH, Milner J, Corey P, et al. Sources of variance in 24hour dietary recall data: implications for nutrition study design and interpretation. Am. J. Clin. Nutr. 1979; 32: 2456-9.

18 Cole TJ, Black AE. Statistical aspects in the design of dietary surveys. In: The Dietary Assessment of Populations. MRC Environmental Epidemiology Unit Report No 4. Southampton: MRC Environmental Epidemiology Unit, 1984; 5-7.

19 Bransby E, Fothergill J. The diets of young children. $\mathrm{Br}$. J. Nutr. 1954; 8: 195-204.

20 Crawford W, Broadley H. The People's Food. London: Heinemann, 1938.

21 Boyd Orr J. Food Health and Income. London: Macmillan, 1936.

22 Minns R. Bombers and Mash, The Domestic Front 19391945. London: Virago, 1980.

23 Ministry of Health and Department of Health for Scotland. Report of the Joint Subcommittee on Welfare Foods. London: HMSO, 1957.

24 Gibson A, Smout TC. From meat to meal: changes in diet in Scotland. In: Geissler C, Oddy DJ, eds. Food, Diet and Economic Change Past and Present. Leicester: Leicester University Press, 1993; 11-34.

25 Campbell RH. Diet in Scotland; an example of regional variation. In: Barker TC, Mckenzie JC, Yudkin J, eds. Our Changing Fare. London: Macgibbon and Kee, 1966; 47-60.

26 Hill EMA. Nutritional aims versus habit and custom. Proc. Nutr. Soc. 1948; 2: 81-5.

27 Cathcart EP, Murray AMT. An Inquiry into the Diet of Families in the Highlands and Islands of Scotland. MRC Special Report Series No. 242. London: HMSO, 1940.

28 Baxter IA, Schroder MJA. Vegetable consumption among Scottish children: a review of the determinants and proposed strategies to overcome low consumption. Br. Food J. 1997; 99(10): 380-7.

29 Smith WCS, Tunstall-Pedoe H, Crombie IK, Tavendale R. Concomitants of excess coronary deaths - major risk factor and lifestyle findings from 10,359 men and women in the Scottish Heart Health Study. Scot. Med. J. 1989; 34: 550-5.

30 Todd S, Woodward M, Bolton-Smith C, Tunstall-Pedoe H. An investigation of the relationship between antioxidant vitamin intake and coronary heart disease in men and women using discriminant analysis. J. Clin. Epidemiol. 1995; 48: $297-305$.

31 Strandhagen E, Hansson P-O, Bosaeus I, Isaksson B, Eriksson $\mathrm{H}$. High fruit intake may reduce mortality among middle-aged men. The study of men born in 1913. Eur. J. Clin. Nutr. 2000; 54: 337-41.

32 Hallfrisch J, Scholfield DJ, Behakll KM. Diets containing soluble oat extracts improve glucose and insulin responses of moderately hypercholesterolemic men and women. Am. J. Clin. Nutr. 1995; 61: 379-84.

33 Lloyd JK. Cholesterol: should we screen all children or change the diet of all children. Acta Paed. Scand. Suppl. 1991; 373: 66-72.

34 Leon D, Ben-Shlomo Y. Pre-adult influences on cardiovascular disease and cancer. In: Kuh D, Ben-Shlomo Y, eds. $A$ Life Course Approach to Chronic Disease Epidemiology. Oxford: Oxford University Press, 1997; 45-77.
35 Stary HC. Macrophages, macrophage foam cells, and eccentric intimal thickening in the coronary arteries of young children. Atherosclerosis 1987; 64: 91-108.

36 Mann SL, Wadsworth MEJ, Colley JRT. Accumulation of factors influencing respiratory illness in members of a national birth cohort and their offspring. J. Epidemiol. Community Health 1992; 46: 286-92.

37 Shaheen S, Barker DJP. Early lung growth and chronic airflow obstruction. Thorax 1994; 49: 533-6.

38 Strachan DP, Cox BD, Erzinclioglu SW, Walters DE, Whichelow MJ. Ventilatory function and winter fresh fruit consumption in a random sample of British adults. Thorax 1991; 46(9): 624-9.

39 Britton JR, Pavord ID, Richards KA, et al. Dietary antioxidant vitamin intake and lung function in the general population. Am.J. Resp. Crit. Care Med. 1995; 151: 1383-7.

40 Braddon FEM, Wadsworth MEJ, Davies JMC, Cripps HA. Social and regional differences in food and alcohol consumption and their measurement in a national birth cohort. J. Epidemiol. Community Health 1988; 42: 341-9.

\section{Appendix - Food rationing in 1950}

After the extreme shortages and stringent rationing of the immediate post-war years, the first half of 1950 showed great improvements in food supply and availability. By June 1950, when the majority of the diet records were obtained, many of the controls had just been finally relaxed, although rationing was still in force for some foods, as shown in Table A1 below. Bread, potatoes, milk, fruit and vegetables were not rationed, but fruit and vegetables were mainly confined to those that were grown in the UK and in season at the time. Eggs were unrestricted between March and September 1950. By the winter of 1950 rations were largely unchanged with the exception of the meat ration, which was lowered. There were also special allocations of sugar and fats for Christmas.

Table A1 Rations per person in June $1950^{14}$

\begin{tabular}{ll}
\hline Bacon and ham & $5 \mathrm{oz}(142 \mathrm{~g})$ per week \\
Cheese & $2 \mathrm{oz}(57 \mathrm{~g})$ per week \\
Butter & $4 \mathrm{oz}(114 \mathrm{~g})$ or $6 \mathrm{oz}(170 \mathrm{~g})$ per alternating \\
& week \\
Margarine & $4 \mathrm{oz}(114 \mathrm{~g})$ per week \\
Cooking fats & $2 \mathrm{oz}(57 \mathrm{~g})$ per week \\
Meat* $^{*}$ & $\begin{array}{l}\text { Cost equivalent of } 6 \mathrm{oz}(170 \mathrm{~g}) \text { carcass meat } \\
\text { and } 2 \mathrm{oz}(57 \mathrm{~g}) \text { corned beef per week }\end{array}$ \\
Eggs & 125 allocations per year $(1$ egg per allocation) \\
Tea & $2.5 \mathrm{oz}(71 \mathrm{~g})$ per week (but no ration for \\
& children under five) \\
Sugar & $8 \mathrm{oz}(227 \mathrm{~g})$ per week \\
Chocolate/sweets & $20 \mathrm{oz}(568 \mathrm{~g})$ per 4 weeks
\end{tabular}

*This was the ration for children under five, which was half the adult ration. 